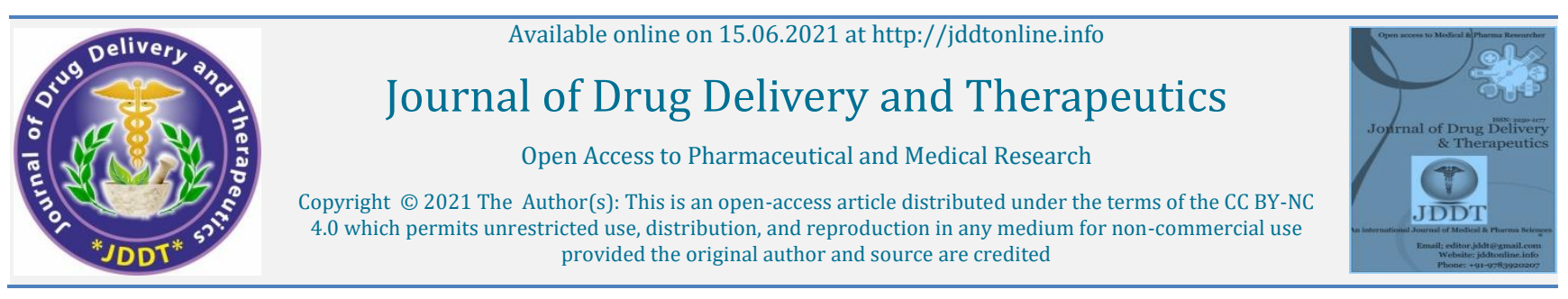

Open Access Full Text Article

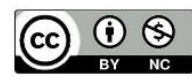

Review Article

\title{
Aegle marmelos (L.) (Bael): A Systematic Review
}

\author{
Savita*, Ajeet Pal Singh, Amar Pal Singh \\ St. Soldier Institute of Pharmacy, Lidhran Campus, Behind NIT (R.E.C), Jalandhar-Amritsar by pass NH-1 Jalandhar-144011, Punjab, India
}

Article Info:
Aeceived 12 April 2021
Accepted 07 June 2021

Abstract

Aegle marmelos is a plant in the Rutaceae family that is one of the most significant in the medicinal field due to its properties. Bilwa is used to treat a variety of medical problems. Since the time of the dinosaurs, this plant has existed. The plant contains a variety of pharmacological qualities, including wound healing, antipyretic potential, antidiarrheal activity, Diuretic activity, Ulcer healing, and more. Antithyroid activity, Immunomodulatory activity, Antifungal activity, Antimicrobial activity, Antioxidant activity, Radioprotective effect, Contractile activity, Antiarthritis activity, Analgesic activity, Cytoprotective effectuate-constipating effect. Alkaloids, Terpenoids, Vitamins, Coumarins, Tannins, Carbohydrates, Flavonoids, Fatty Acids, Essential Oils, and other miscellaneous chemicals are among the identified constituents. This study summarises information about the A. marmelos' morphology, distribution, phytochemistry, traditional uses, and biological activity.

Keywords: Aegle marmelos, Phytochemistry, morphology, pharmacological properties.

\section{Introduction}

Plants are particularly significant to humans since they contain various active ingredients that are the precursor for the creation of many drugs ${ }^{1}$. For thousands of years, plants have been used in India as natural or herbal medicine. Plants used in Indian medicines are regarded as a rich source of numerous pharmacologically active principles and active ingredients, which are often employed in home treatments for a variety of diseases ${ }^{2}$. Aegle marmelos (L.) Correa ( $A$ marmelos), often well-known for Bael and belongs to the Rutaceae family, has been widely employed in indigenous systems of Indian medicine due to its many therapeutic characteristics ${ }^{3}$. A. marmelos leaves are presented to Lord Shiva, whose devotion would be incomplete without them.Shivadurme, or Shiva's tree, is another name for it. Ancient Indian texts such as the Yajurveda and the Mahabharata 4 .Bael includes a variety of phytochemicals such as alkaloids, tannins, essential oils, gums, resins, coumarin, and polysaccharide, which makes it effective for a variety of diseases. When compared to other fruits, it has a substantially higher nutritional value. It is also quite important in terms of the environment.

\section{Synonyms ${ }^{5}$}

Hindi (Bel, bael, sripal); Sanskrit (Bilva, sriphal, shivadruma, Shivapala); Telugu (Maredu); Bengali Cambodia (Phneou or pnoi); Vietnamese (Baunau); Malayan (M (Modjo). (Bel); Gujrati (Bil); Kannada (Bilpatra, kumbala, malura); Tamil (Kuvalum); Thai (Matum and mapin);

\section{Ecology 6}

Bael is of Indian origin and can be found in Bangladesh, Egypt, Malaysia, Myanmar, Pakistan, Sri Lanka, and Thailand. The tree fills wild in dry woodlands on the slopes and fields of focal and southern India, just as in Burma, Pakistan, and Bangladesh, just as in blended deciduous and dry timberlands.

\section{Botanical Description}

It is a slow growing medium to small size tree that can reach a height of 25 to 30 feet.The steam is soft and dense, with a few spiky branches. Table 1 contains the whole botanical description of $A$. marmelos ${ }^{7}$. 
Table 1: Botanical Description of Aegle marmelos (L.)

\begin{tabular}{|l|l|}
\hline Plant Part & Morphological characteristics \\
\hline Bark & $\begin{array}{l}\text { The bark grey or brownish in colour, and it bears a number of long, straight spines. It includes gums, which } \\
\text { form from wounded branches and harden over time. The easiest way to describe these gums is a } \\
\text { transparent, sticky sap. It tastes good at first, but it quickly gets irritating to the throat. }\end{array}$ \\
\hline Leaf & $\begin{array}{l}\text { It has trifoliate leaves with a circular base and a pointed apex. The adult leaves are dark green, whilst the } \\
\text { young leaves are pale green. }\end{array}$ \\
\hline Flower & The flowers are bisexual and greenish or yellowish in colour.It is usually evident with fresh leaves. \\
\hline Fruit & $\begin{array}{l}\text { The bael fruit has a tough outer jacket with a diameter of around } 5 \text { to } 12 \mathrm{~cm} . \\
\text { It is green while unripe and turns yellowish brown when ripe. Its interior includes up to } 20 \text { orange pulp. }\end{array}$ \\
\hline Seed & They are small (almost $1 \mathrm{~cm}$ long), hard, hairs, flattened-oblong and each is surrounded by an adhesive sac. \\
\hline
\end{tabular}

\section{Traditional utilization of Aegle marmelos}

A. marmelos is extensively described in Vedic literature for the treatment of a variety of diseases.

It has long been used to cure a range of ailments ${ }^{8-14}$, which are summarised in Table 2.

Table 2: Various parts of Aegle marmelos utilized

\begin{tabular}{|c|c|}
\hline Plant part & Traditional utilization \\
\hline Leaf & $\begin{array}{l}\text { Sore, spinal pain, eye grievances, stomach problems, retching, trims and wounds, ulcer, dropsy, beriberi, } \\
\text { heart shortcoming, cholera, the runs, cardio tonic, glucose, creature wounds, neurological issues, hair } \\
\text { tonic, intense bronchitis. In anesthetized felines, veterinary medicine for wounds, worm murdering, } \\
\text { feed for sheep, goats, and steers, incitement of breath and withdrawal of denervosed nictitating film. }\end{array}$ \\
\hline Fruit & $\begin{array}{l}\text { Astringent, looseness of the bowels, gastric issues, blockage, purgative, tonic, stomach related, } \\
\text { stomachic, diarrhea, mind and heart tonic, ulcer, antiviral, intestinal parasites, gonorrhea, epilepsy. }\end{array}$ \\
\hline Root & $\begin{array}{l}\text { Dog chomp, gastrointestinal issues, heart sicknesses, discontinuous fevers, antiamoebic, hypoglycaemic, } \\
\text { stiffness. }\end{array}$ \\
\hline Bark & Stomach problem, discontinuous fevers, heart issue. \\
\hline Seed & Febrifuge. \\
\hline Flower & Expectorant, epilepsy. \\
\hline Whole plant & $\begin{array}{l}\text { Stomach torment, sore, astringent, spinal pain, canine nibble, bosom torment, cholera, blockage, } \\
\text { seizures, cramp, diabetes, loose bowels, diarrhea, fever, eye grievances, gastric difficulty, stomach } \\
\text { issues, jaundice, purgative, queasiness, night fever, heart issues, snakebite, stomach problem, heaving, } \\
\text { tonic, cut and wounds. }\end{array}$ \\
\hline Root, Bark & Fish poison. \\
\hline Seed mucilage & Plaster for walls. \\
\hline Seed oil & Laxative. \\
\hline Wood & Globules utilized by the lower stations, and exceptional couches for rheumatoid patients \\
\hline Gum around seed & To increase the adhesion strength of water paints. \\
\hline $\begin{array}{l}\text { Unripe fruit rind, } \\
\text { Bark }\end{array}$ & Yellow dye \\
\hline Stem & Oil and sugar mill pestles. \\
\hline
\end{tabular}

\section{Biophysical limits ${ }^{15}$}

Bael is located at an elevation of 0-1200 meters; it requires an annual temperature range of 6 to 48 degrees Celsius and an annual rainfall range of 570 to 2000 millimetres. Furthermore, it demands well-drained soil and grows best in rocky soils and alkaline with pH levels ranging from 5 to 8.
Taxonomy ${ }^{5,16}$

Kingdom: Plantae Order: Sapindales Family: Rutaceae Sub family: Aurantioideae Genus: Aegle Species: A. marmelos 


\section{Phytochemistry}

A few investigations have been led to discover dynamic compound fixings from different areas of the bael plant ${ }^{2,7,17-18 . T a b l e ~} 5$ lists the chemical compounds extracted from A. marmelos.

Table 3: Plant Part Chemical Constituents

\begin{tabular}{|l|l|}
\hline Plant part & Chemical Constituents \\
\hline Leaf & $\begin{array}{l}\text { Skimmianine, Aeglin, Rutin, -sitosterole, -sitosterol, Flavone, Lupeol, Cineol, Citral, Glycoside, 0- } \\
\text { isopentenyl, Hallordiol, Mameline, Citronellal, Cuuminaldehyde phenylethyle cinnamamides, Euginol, }\end{array}$ \\
\hline Fruit & $\begin{array}{l}\text { Psoralen, Marmelide, Tannin, Phenol, Marmelosin, Luvangetin, Aurapten, Tannin, Phenol, Tannin, } \\
\text { Tannin, Tannin, Tannin, Tannin, Tannin, Tannin, }\end{array}$ \\
\hline Bark & Alkaloids, Fagarine, Marmin, Furoquinoline \\
\hline Seed & D-limonene, A-D-phellandrene, Cineol, Citronellal, Citral, P-cyrnene, Cumin aldehyde are essential oils. \\
\hline Root & Terpines, Halopine, Coumarins, and Alkaloid \\
\hline
\end{tabular}

\section{Pharmacological studies}

A. marmelos is one of the most frequently utilised medicinal and nutritional plants in the Rutaceae family. This plant has recently been found to have a variety of therapeutic benefits shown in Figure 1.

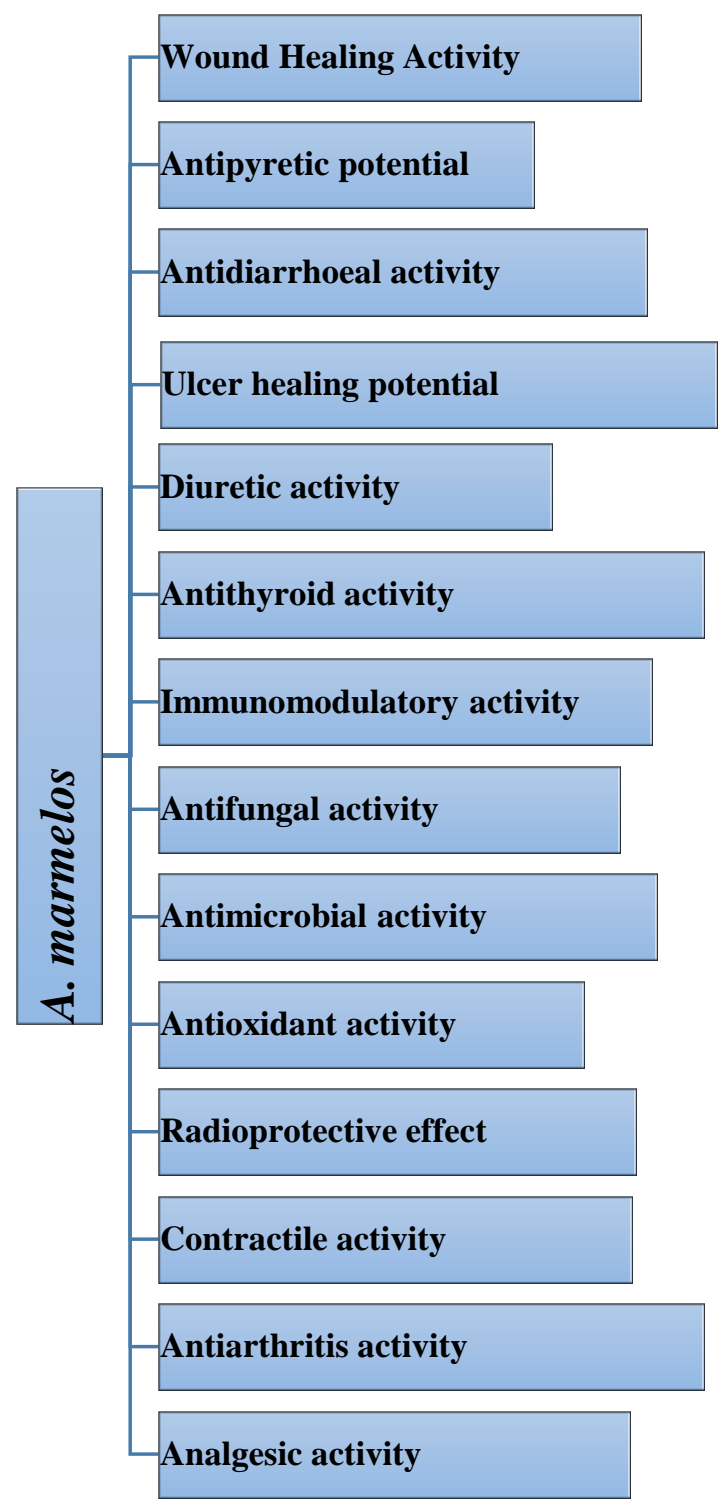

Figure 1: Pharmacological activities of $A$. marmelos

\section{Wound Healing Activity}

The impact of skin and intraperitonial organization of methanolic concentrates of Aegle marmelos balm and infusion on two sorts of twisted models in rodents, extraction and entry point, was explored. The infusion and salve of Aegle marmelos methanolic separate got critical reactions in both. As proven by an increment in elasticity in the entry point model, the concentrate helps in the mending cycle. The outcomes were likewise contrasted with those of the criticized drug nitrofurazone 7,19.

\section{Antipyretic potential}

A. marmelos' antipyretic movement on Brewer's yeast actuated pyrexia in pale skinned person rodents. They show that at portions of $200 \mathrm{mg} / \mathrm{kg}$ body weight and $400 \mathrm{mg} / \mathrm{kg}$ body weight, the ethanolic extricate created a critical (P0.001) decrease in high internal heat level in a dose subordinate way. The concentrates' antipyretic viability was similar to that of paracetamol (100 mg/kg body weight) ${ }^{20}$.

\section{Antidiarrhoeal activity}

The antidiarrheal activity of a chloroform extract of $A$. marmelos root. In an in vitro research, the extract was found to be equivalent to ciprofloxacin and mostly active against Vibrio cholerae bacteria, followed by Escherichia coli (E. coli) and Shigella spp ${ }^{21}$.

The antimalarial activity of alcoholic extracts of $A$. marmelos seeds and leaves was tested in vivo and in vitro against the Plasmodium berghei NK65 strain. The seeds were schizontocidal in both systems, while the leaves were solely schizontocidal in the in vitro system ${ }^{22}$.

\section{Ulcer healing}

In albino rats, $A$. marmelos fruit pulp extract lowers mucosal thickness, superoxide dismutation, catalase activity, and glutathione levels considerably. Ulcer index, aspartate aminotransferase, alanine aminotransferase, and lipid peroxidation activity all increased significantly. These data suggest that an antioxidant mechanism may impact $A$. marmelos' gastroduodenal preventative and antiulcerogenic effects. ${ }^{23}$.

\section{Diuretic activity}

Several organic extracts and fractions of A. marmelos fruit were studied for their diuretic properties. The extracts were administered to the rats at dosages of 300,400 , and 500 $\mathrm{mg} / \mathrm{kg}$ intraperitoneally.To examine the diuretic impact, they 
analysed urine volume and salt content in urine. They observed that the ethanolic extract generated a significant increase in sodium excretion at the higher dosage (500 $\mathrm{mg} / \mathrm{kg}$ ).Petroleum ether, chloroform, and ethyl acetate fractions are also effective 24 .

\section{Antithyroid activity}

Thyroid hormone levels were lowered when the leaves of A.marmelos were extracted. It was due to the presence of scopoletin, which has a stronger therapeutic effect than the propylthiouracil drug. ${ }^{2}$.

\section{Immunomodulatory activity}

It was discovered that methanolic leaves extract of Aegle marmelos stimulate cell mediated and antibody mediated immune responses in rats. However, a low dose of methanolic extract of Aegle marmelos was found to be most effective in cell mediated immune response, whereas a high dose was found to be most effective in humoral immunity ${ }^{25}$.

\section{Antifungal activity}

Essential oil from Aegle marmelos leaves may meddle with the $\mathrm{Ca} 2+$-dipicolonic corrosive metabolic pathway and maybe limit spore improvement, as per an examination. A.marmelos leaf removes in ethanol, methanol, and water showed antifungal adequacy against dermatophyte organism 26.

\section{Antimicrobial activity}

It has been stated that $A$. marmelos has traditionally been used to treat a variety of infectious disorders by inhibiting a wide range of harmful microorganisms. The antibacterial activity of $A$. marmelos leaves and fruit extract was investigated. The use of leaf and fruit extracts against Roultella plantikola resulted in inhibition zones of $11 \mathrm{~mm}$ and $9 \mathrm{~mm}$, respectively. The plant extract produced a maximum inhibition zone of $(18 \mathrm{~mm})$ activity against the fungal strain Penicillium chrysogenum and a minimum inhibition zone of $(7 \mathrm{~mm})$ activity against Candida albicans ${ }^{27}$.

\section{Antioxidant activity}

The DPPH radical scavenging method, the reducing power assay, the nitric oxide scavenging assay, the superoxide radical scavenging assay, the ABTS radical scavenging assay, and the H2O2 radical scavenging assay were used to determine the antioxidant activity of $A$. marmelos fruit pulp methanolic and aqueous extract. The antioxidant activity of both the aqueous and alcoholic extracts was high. Unripe fruit likewise showed a greater free radical inhibition percentage than ripe fruit. ${ }^{28}$.

\section{Radioprotective effect}

One of the most important cancer therapies, especially for those with critical visceral tumours, is radiotherapy. It has certain bad side effects, despite the fact that it is quite valuable all over the world. In mice exposed to various amounts of gamma radiation, the radioprotective effect of bael fruit hydroalcoholic extract was investigated. Before being subjected to 10 Gy 60Co gamma-rays, Swiss albino male mice were administered $5,10,15,20$, or $40 \mathrm{mg} / \mathrm{kg}$ Aegle marmelos extract intraperitoneally every day for 5 days. After 30 days of post-radiation therapy, the majority of survivors report maximum protection ${ }^{29}$.

\section{Contractile activity}

The contractile action of Aegle marmelos leaves alcoholic extract was discovered on guinea pig separated ileum and tracheal chain due to its traditional usage in treating asthma and associated disorders. The alcoholic extract of $A$. marmelos leaves at low and high dosages of $1 \mathrm{mg} / \mathrm{ml}$ and 2 $\mathrm{mg} / \mathrm{ml}$ caused the guinea pig ileum and tracheal chain to relax the most owing to $\mathrm{H} 1$ receptor depression ${ }^{30}$.

\section{Antiarthritis activity}

The leaves of Aegle marmelos were found to be anti-collagen in Wistar albino rats, causing arthritis ${ }^{31}$.

\section{Analgesic activity}

Writhing and tail immersion tests were used to investigate the antinociceptive effect of $A$. marmelos leaves methanol extract in mice. The greatest possible impact of methanolic extract $(200 \mathrm{mg} / \mathrm{kg}$ p.o.) was statistically significant when compared to other dosages. It is concluded that the methanol extract of A. marmelos leaves has a potent analgesic effect ${ }^{32}$.

\section{Cytoprotective effect}

This effect has been found in the freshwater fish Cyprinus carpio.For 1, 8, 16, and 32 days, experimental fish were maintained at sublethal metal ion concentrations. After 32 days, the fish were fed Aegle marmelos crude powder (500 $\mathrm{mg} / \mathrm{kg}$ diet).By stabilising the plasma membrane and regulating the antioxidant enzyme system, the therapy produced a cytoprotective effect. ${ }^{33}$.

\section{Anti-constipating effect}

The majority of the available ripe fruits are thought to be a natural remedy for various types of laxatives. The fruits of $A$. marmelos are commonly used to cleanse and tone the gut. Consuming this fruit on a regular basis for two to three months helps in the evacuation of old accumulated faecal matter from the colon. It is commonly consumed in the form of'sherbat,' which is formed from ripe fruit pulp ${ }^{34}$.

\section{Anticancer activity}

The effects of Aegle marmelos fruit extract on breast cancer in rats generated by 7, 12-dimethylbenz(a )anthracene (DMBA). The study employed female Charles Foster rats that were 55-60 days old and weighed approximately (150 $10 \mathrm{~g}$ ). They were stimulated orally with DMBA $(20 \mathrm{mg} / \mathrm{mL}$ diluted in Olive oil). The rats were given Aegle marmelos ethanolic fruit pulp extract (200 mg/kg b.w./day) orally for 5 weeks after developing breast tumours (approximately $0.5 \mathrm{~cm}$ ) and the amount of tumour was assessed. Treatment with Aegle marmelos resulted in a substantial reduction in breast tumour volume ( $\mathrm{P}$ 0.05), as well as a substantial drop ( $\mathrm{P}$ 0.0001) in serum biomarkers such as TNF-, serum malondialdehyde (MDA), and glucose levels. In a rat model, the ethanolic fruit pulp extract has anti-proliferative effect by slowing the progression of breast cancers. ${ }^{35}$

\section{Transcriptome Analysis}

The transcripts of $A$. marmelos were also annotated using information from other Rutaceae species, such as Citrus clementina and Citrus sinensis.482 transcripts were classified as cytochrome p450s (CYPs), whereas 314 transcripts were classified as glucosyltransferases (GTs).The monoterpenoid biosynthesis pathway found the most prevalent in A. marmelos leaves. A total of 133,616 contigs were assembled into 46,335 unigenes with lengths ranging from 201 to $14,853 \mathrm{bp}$.There were 7002 transcription factors and 94,479 SSR markers in the study ${ }^{36}$.

\section{Antidiabetic activity}

The circulatory alterations in alloxan-induced diabetic rats treated with Aegle marmelos methanolic leaf extracts. The study included five treatment groups of methanolic leaf extracts: control, diseased, low dosage $(100 \mathrm{mg} / \mathrm{kg})$, medium dose $(250 \mathrm{mg} / \mathrm{kg})$, and high dose $(500 \mathrm{mg} / \mathrm{kg})$.Very-Low- 
Density Lipoprotein (VLDL), Serum Sialic Acid, Glutathione Peroxidase, Serum Catalase, Ascorbic acid, Sodium, Potassium, and Chloride levels were used to assess the cardiovascular effects. When compared to the sick treatment groups, the high dosage treatment group had significantly lower levels of Very Low-Density Lipoprotein (VLDL), Serum Sialic Acid, Glutathione Peroxidase, Serum Catalase, Ascorbic acid, Sodium, Potassium, and Chloride. When compared to the high dosage treatment group as well as the sick group, low and medium dosage treated animals exhibited no significant change in these cardiovascular parameters ${ }^{37}$.

\section{Food applications}

The health advantages of bael are not confined to the edible section (fruit), but also include the non-edible portions (root, trunk, bark, leaf, blossom, and seed), which contain biologically active substances in equivalent amounts. With growing awareness of the importance of diet for human wellbeing among health-conscious consumers, interest in functional foods has grown. As a result, research into the functional attributes of various under utilised plants has been reaffirmed, and various sources have emerged as suitable food material for the processing industry. Several research publications gathered from diverse bibliometric sources showed that $A$. marmelos and its bioactive ingredients might play a key role in the prevention of oxidative stress-related chronic and degenerative disorders. The focus of this study is on contemporary scientific information on A. marmelos nutrition and bioactive profile, health benefits, clinical and nonclinical studies of various phytoconstituents, and A. marmelos potential in the food processing sector for diverse food items ${ }^{38}$.

\section{Conclusion}

Several parts of A. marmelos have been classified as traditional healers, capable of curing a wide range of human ailments. There are several phytoconstituents in A. marmelos that are significant components in the plant's medicinal effectiveness. Almost every part of this plant is used to cure a variety of illnesses, including the leaf, fruit, seed, bark, and root. Given the Bael tree's great potential, it should either be cultivated or preserved in order to maximize its potential for exploitation and the discovery of new and effective herbal treatments. To produce goods for better economic and therapeutic usage, a comprehensive research and development effort should be undertaken.

\section{Disclosure Statement}

There are no conflicts of interest.

\section{Acknowledgment}

It's our privilege to express profound sense of gratitude and cordial thanks to our respected chairman Mr. Anil Chopra, Vice Chairperson Ms. Sangeeta Chopra \& Pro-Chairman Mr. Prince Chopra, St. Soldier Educational Society, Jalandhar for providing the necessary facilities to complete this work.

\section{References}

1. Dhankhar S, Ruhil S, Balart M, Dhankhar S, Chhillar AK. A. marmelos (Linn.) Correa: A Potential Source of Phytomedicine. J of Med Plants Res 2011; 5(9):1497-507.

2. Sharma PK, Bhatia V, Bansal N, Sharma A. A review on bael tree. Natural Product Radiance. 2007; 6(2):171-8.

3. Brijesh S, Daswani P, Tetali P, Antia N, Birdi T. Studies on the antidiarrhoeal activity of Aegle marmelos unripe fruit: validating its traditional usage. BMC Complement Altern Med 2009; 9(1):47 https://doi.org/10.1186/1472-6882-9-47
4. Asha J, Krishan K. Tremendous Pharmacological Values of Aegle marmelos. Int J of Pharm Sci Rev and Res 2016; 36(2):121-127.

5. Kaur A, Kalia M. Physicochemical Analysis of Bael (Aegle marmelos) Fruit Pulp, Seed and Pericarp J. Chem Sci Review and Letters 2017: 6(22); 1213-1218.

6. http://www.kannadigaworld.com.

7. Lambole VB, Murti K, Kumar U, Sandip kumar PB, Gajera V. Phytopharmaco $\neg$ logical properties of Aegle marmelos as a potential medicinal tree. Int J of Pharm Sci Rev and Res 2010; 5(2):67-72.

8. Jain SK. Dictionary of Indian Folk Medicine and Ethno-botany. Deep Publications, New Delhi. 1991; 311.

9. Grieve M, Leyel CF. A Modern Herbal, Tiger Books International, London. 1992; 770.

10. Gaur RD. Flora of the district Garhwal North West Himalaya with ethnobotanical notes, Trans Media, Srinagar Garhwal. 1999; 811.

11. Kaushik P, Dhiman AK. Medicinal Plants and Raw Drugs of India, Bishen Singh Mahendra Pal Singh, Dehradun. 1999; 623.

12. Veerappan AK, Srinivasan RD. Cardiotonic effect of A. marmelos Corr. on amphibian heart in-situ preparation. Proc 6th Internet World Congress for Biomedical Sciences. 2000.

13. George KV, Mohanan N, Nair SS. Ethnobotanical investigations of A. marmelos (Linn) Corr, in: Ethnobotany and Medicinal Plants of India and Nepal, by Singh V and Jain AP, Scientific Publishers, Jodhpur. 2003; 29-35.

14. Malviya R, Kumar A., Singh A. and Kulkarni G.T., Pharmacological Screening, Ayurvedic Values and Commercial Utility of Aegle marmelos, Int.J. Dru. Dev. Res. 2012; 4(1):28-37.

15. Wirth EH. Soil and plant analysis. Inter science Publication, New York. 1946: 35(6):192-192. https://doi.org/10.1002/jps.3030350611

16. Sharma N, Dubey W. History and Taxonomy of Aegle marmelos: A Review Inter J. Pure Applied Bioscience 2013; 1(6):7-13.

17. Sugeng R, Mohd.Aspollah S, Mawardi R, Gwendoline CL. Ee1m. Taufiq-Yap, Norio A,Mariko Alkaloids from Aegle marmelos. Malaysian J of Ana Sci 2001, 7(2):463-465.23.

18. Laphookhieo S, Phungpanya Chalita, Tantapakul C, Techa S, Suphara T,Narmdorkmaiet W. Chemical constituents from Aegle marmelos. J. Braz.Chem.Sac 2011; 22(1):176-178.24. https://doi.org/10.1590/S0103-50532011000100024

19. Jaswanth A, Akilandeswari L, Manimaran V, Ruckmani S. Wound healing activity of Aegle marmelos. Ind J Pharm Sci. 2001; 63(1):41-4.

20. Atul NP, Nilesh VD, Akkatai AR, Kamlakar SK. A review on Aegle marmelos: a potential medicinal tree. Int Res J Pharm 2012; 3(8):86-91.

21. Mazumder R, Bhattacharya S, Mazumder A, Pattnaik AK, Tiwary PM, Chaudhary S. Antidiarrhoeal evaluation of Aegle marmelos (Correa) Linn. root extract. Phytother Res 2006; 20(1):82-84 https://doi.org/10.1002/ptr.1804

22. Dhankhar S, Ruhil S, Balhara M, Dhankhar S, Chhillar A. Aegle marmelos (Linn.) Correa: A potential source of phytomedicine. J Med Plant Res 2011; 5(9):1497-1507.

23. Madhu C, Hindu K, Sudeepthi C, Maneela P, Reddy KV, Sree BB. Anti ulcer activity of aqueous extract of Aegle marmelos leaves on rats. Asian J Pharm Res 2012; 2(4):132-135

24. Singh S, Singh SK, Srivastava S, Singh P, Trivedi M, Shanker P, et al. Experimental evaluation of diuretic activity of Aegle marmelos in rats. Int J Pharm Biol Sci 2013; 3(1):98-102.

25. Govinda HV, Asdaq SMB. Immunomodulatory potential of methanol extract of Aegle marmelos in animals. Ind j of pharma sci 2011 73(2):235. https://doi.org/10.4103/0250-474X.91571

26. Balakumar S, Rajan S, Thirunalasundari T, jeeva S. Antifungal activity of Aegle marmelos (L.) Correa (Rutaceae) leaf extract on 
dermatophytes. Asian Pacific J of Trop Bio.2011; 1(4):309-312. https://doi.org/10.1016/S2221-1691(11)60049-X

27. Meena R, Pareek A, Meena RR. Antimicrobial activity of Aegle marmelos (Rutaceae) plant Extracts. Int J of Medi Pharm Res 2016; 2(1):1-5.

28. Sharmila S, Devi PAV. A review on: Aegle marmelos. Journal of Pharmacy Research. 2011; 4:720-2.

29. Jagetia GC, Venkatesh P, Baliga MS. Evaluation of the radioprotective effect of A. marmelos (L) Correa in cultured human peripheral blood lymphocytes exposed to different doses of gamma-radiation: a micronucleus. Mutagenesis. 2003; 18(4):387-93 https://doi.org/10.1093/mutage/geg011

30. Arul V, Miyazaki S, Dhananjayan R. Mechanisms of the contractile effect of the alcoholic extract of A. marmelos Corr. on isolated guines pig ileum and tracheal chain. Phytomedicine. 2004; 11(78):679-83. https://doi.org/10.1016/j.phymed.2002.12.001

31. Vogel HG. 2nd ed. New York: Springer; Analgesic, antiinflammatory and antipyretic activity in Drug discovery and evaluation pharmacological assays. 2002; 759-67.

32. Shankarananth V, Balakrishnan N, Suresh D, Sureshpandian G, Edwin E, Sheeja E. Analgesic activity of methanol extract of A. marmelos leaves. Fitoterapia. 2007; 78(3):258-9. https://doi.org/10.1016/j.fitote.2006.12.004
33. Vinodhini R, Narayanan M. Cytoprotective effect of Nelumbo nucifera and Aegle marmelos in common crap exposed to heavy metals. International Journal of Integrative Biology. 2009; 7(2):124-9.

34. Sharma PK, Bhatia V, Bansal N, Sharma A. A review on bael tree. Natural Product Radiance. 2007; 6(2):171-8.

35. Akhouri V, Kumari M, Kumar A. Therapeutic effect of Aegle marmelos fruit extract against DMBA induced breast cancer in rats Scientific Reports, 2020;10(1): 18016 https://doi.org/10.1038/s41598-020-72935-2

36. Kaushik, P, Kumar S.Transcriptome Analysis of Bael (Aegle marmelos (L.) Corr.) a Member of Family Rutaceae. Forests, 2018; 9(8):450. https://doi.org/10.3390/f9080450

37. Ravi BB, Padmavathi PM, Manoharan SK. Effects of Aegle marmelos (L.) Methanolic Leaf Extracts on Cardiovascular Parameters in Diabetic Rats, Journal of Diseases and Medicinal Plants 2020; 6(4):77-81.

38. Venthodika A, Chhikara N, Mann S, et al. Bioactive compounds of Aegle marmelos L., medicinal values and its food applications: A critical review. Phyto Res PTR. 2021; 35(4):1887-1907 https://doi.org/10.1002/ptr.6934 